\title{
Impact of solar ultraviolet radiation on hatching of a marine copepod, Calanus finmarchicus
}

\author{
Carolina Alonso Rodriguez ${ }^{1,2}$, Howard I. Browman ${ }^{1, *}$, Jeffrey A. Runge $^{1}$, \\ Jean-François St-Pierre ${ }^{1}$
}

\author{
${ }^{1}$ Maurice-Lamontagne Institute, Department of Fisheries and Oceans Canada, Division of Ocean Sciences, PO Box 1000, \\ 850 Route de la Mer, Mont-Joli, Québec G5H 3Z4, Canada \\ ${ }^{2}$ Département d'océanographie, Université du Québec à Rimouski, 310, allée des Ursulines, Rimouski, \\ Québec G.5L 3A1, Canada
}

\begin{abstract}
The calanoid copepod Calanus finmarchicus is a key component of the zooplankton community in the estuary and Gulf of St. Lawrence, Canada. During the spring and summer months, C. finmarchicus eggs are released into the shallow $(0$ to $15 \mathrm{~m}$ ) mixed surface layer, where they incubate for 1 to $3 \mathrm{~d}$. Radiometric measurements in this region show that biologically significant levels of solar ultraviolet radiation ( $U V=280$ to $400 \mathrm{~nm}$ ) penetrate into the mixed surface layer. Thus, C. finmarchicus eggs are potentially susceptible to UV-induced mortality. This possibility was evaluated by incubating C. finmarchicus eggs in an outdoor reservoir under natural sunlight. There were 3 spectral exposures regimes [UV-B (280-320 nm) + UV-A $(320-400 \mathrm{~nm})+$ PAR $(400-700 \mathrm{~nm})$; UV-A+PAR; PAR only]. Control groups were kept in the dark. Incubations were conducted at depths of 2 and $60 \mathrm{~cm}$ and the percentage of eggs that hatched was determined following 2 to $3 \mathrm{~d}$ exposures in 3 independent experiments. Both the UV-B+UV-A+PAR and the UV-A+PAR treatments exhibited low percent hatching compared to the PAR and dark treatments: UV radiation had a strong negative impact on $C$. finmarchicus eggs. Further, percent hatching in UV-B-exposed eggs was not significantly lower than that in eggs exposed to UV-A only: under natural sunlight, UV-A radiation appeared to be more detrimental to C. finmarchicus embryos than UV-B. UV penetration into the experimental reservoir was similar to that observed in estuarine waters of this region, but lower than the clearer waters of the Gulf of St. Lawrence. This suggests that, at current levels of exposure, UV radiation has a negative effect on C. finmarchicus eggs residing in the first few meters of the water columns in this geographic region.
\end{abstract}

KEY WORDS: UV-B - UV-A - Ozone depletion - Estuary and Gulf of St. Lawrence - Secondary production

\section{INTRODUCTION}

Negative effects of solar ultraviolet-B (UV-B $=280$ to $320 \mathrm{~nm}$ ) radiation on bacterioplankton, phytoplankton and macrophytic algae, zooplankton, and ichthyoplankton have all been documented (see reviews by Holm-Hansen et al. 1993, Siebeck et al. 1994, Häder et al. 1995). However, the broader ecological impacts of UV-B remain unclear, as the processes involved are species- and life stage-specific (e.g. Dey et al. 1988,

\footnotetext{
- Corresponding author. Present address: Institute of Marine Research, Aquaculture Centre, Austevoll Aquaculture Research Station, 5392 Storebø, Norway.

E-mail: howard.browman@imr.no
}

Zagarese et al. 1997), and there are substantial differences between short- and long-term effects (e.g. Bothwell et al. 1993, Cabrera et al. 1997). Moreover, indirect effects can also have significant consequences. For example, UV-B-induced changes in the fatty acid composition of phytoplankton can alter (reduce) its value as a food source for higher trophic organisms (Goes et al. 1994); increased pigmentation in response to UV-B exposure enhances predation risk (Hairston 1979, Morgan \& Christy 1996), and avoidance of the surface layers typically reduces prey encounter rate.

Although UV-B radiation is rapidly attenuated in the water column, it can reach ecologically significant depths (Booth \& Morrow 1997). In the estuary and Gulf of St. Lawrence (Canada), measurements of the diffuse 
attenuation coefficients for UV-B indicated maximum $10 \%$ depths (the depth to which $10 \%$ of the surface irradiance penetrates) of $3 \mathrm{~m}$ at $310 \mathrm{~nm}$ (Kuhn et al. 1999). During the summer, the water column in some regions of the St. Lawrence system is characterized by a steep thermocline (10 to $30 \mathrm{~m}$ ) which separates the surface mixed layer from a cold intermediate layer (Koutitonsky \& Bugden 1991). This pronounced stratification, which coincides with periods of high incident solar radiation, acts as a physical barrier constraining the (non- or minimally motile) early life stages of many planktonic organisms to the shallow mixed layer. Consequently, they may be exposed to relatively high levels of solar UV-B radiation during the summer months.

Calanus finmarchicus is a dominant species of the mesozooplankton community in these waters (de Lafontaine et al. 1991, Runge \& Plourde 1996). This copepod plays a key role in the pelagic food webs of the North Atlantic, since its eggs and nauplii are a predominant prey for larvae of several ecologically and economically important fish species. The first feeding larval stages of some stocks of redfish, cod and haddock feed almost exclusively on Calanus $\mathrm{sp}$. eggs and nauplii (Kane 1984, Runge \& de Lafontaine 1996). Females release their eggs in surface waters, mostly during the spring and summer months (March to September). More than $34 \%$ of the eggs are found in the first $4 \mathrm{~m}$ of the water column, where they may be exposed to UV radiation (Runge \& de Lafontaine 1996, P. Kuhn pers. comm.).

Current levels of UV-B radiation are harmful to planktonic crustaceans. Higher mortality, a shift in the sex ratio, reduced fecundity, morphological malformations in the offspring and altered developmental rates are among the negative effects reported (Karanas et al. 1981, Williamson et al. 1994, Chalker-Scott 1995, Cabrera et al. 1997, Kouwenberg et al. 1999). The role of UV-A radiation (320 to $400 \mathrm{~nm}$ ) is not as clearly defined, although it appears to be involved in the photorepair of UV-B-induced damage (Sutherland 1981). However, several studies have demonstrated its deleterious effects on aquatic organisms (Cullen et al. 1992, Bothwell et al. 1994, Bass \& Sistrun 1997, Williamson et al. 1997). Given that Calanus finmarchicus eggs are potentially at risk in their natural environment, we attempted to determine their tolerance to incident UV radiation. Our specific goal was to evaluate the impact of solar UV-B and UV-A radiation on hatching of $C$. finmarchicus eggs.

\section{MATERIALS AND METHODS}

Eggs were exposed to natural sunlight in a fiberglass reservoir $60 \mathrm{~cm}$ high and $122 \mathrm{~cm}$ wide $\left(0.701 \mathrm{~m}^{3}\right)$ placed on the grounds of the Maurice-Lamontagne Institute

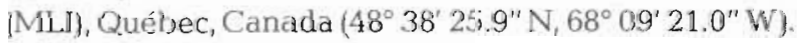

The reservoir contained seawater pumped from the St. Lawrence estuary and filtered through a series of quartz sand filters $(0.8$ to $1.2 \mathrm{~mm}$ grain size, allowing only particles of $<20$ to $40 \mu \mathrm{m}$ to pass). Water in the reservoir was completely replaced approximately every hour.

Radiometry. Spectral irradiance (at $1 \mathrm{~nm}$ intervals) in the reservoir was measured at the beginning of each experiment using an OL754-O-PMT scanning spectroradiometer (Optronic Laboratories, Orlando, FL) outfitted with a WP470 submersible integrating sphere. Measurements were made at the locations in the reservoir where the incubation tubes were suspended (see below). The instrument was calibrated against a NIST. traceable $200 \mathrm{~W}$ tungsten-halogen standard lamp (Optronic Laboratories, model no. OL 752-10) prior to each set of measurements. Ambient terrestrial UV-B radiation ( 287 to $320 \mathrm{~nm}$ at $0.5 \mathrm{~nm}$ intervals) was recorded every $30 \mathrm{~min}$ by a Brewer MKIII double monochromator spectrophotometer (Sci-Tec Instruments Inc., Saskatoon, Saskatchewan) deployed on the roof of the MLI. The Brewer measurements were used to obtain total daily UV-B irradiant exposure during the course of each experiment.

Experimental organisms. Calanus finmarchicus females were collected from the St. Lawrence estuary by vertical haul $(250$ to $0 \mathrm{~m}$ ) using a $1 \mathrm{~m}$ diameter zooplankton net (333 $\mu \mathrm{m}$ mesh) deployed at midday. Immediately after capture, gravid females were placed in $10 \mathrm{l}$ buckets ( 50 copepods bucket ${ }^{-1}$ ) filled with newly filtered seawater $(0.2 \mathrm{~km}$ pore size, salinity of $28 \pm$ 1 psu), where they released their eggs. The buckets were maintained in a temperature-controlled chamber at $6.5^{\circ} \mathrm{C}$. Females were fed once per day on the diatom Skeletonema costatum and the filtered seawater in the buckets was replaced every $2 \mathrm{~d}$. This culture of $S$. costatum is not detrimental to hatching success in $C$. finmarchicus (Ban et al. 1997). For Expt 1, females were collected from the estuary $4 \mathrm{wk}$ prior to the egg collections. For Expt 2, females were collected the day before the experiment and the eggs released that same night were those added to the incubation tubes. For Expt 3, eggs were collected from the Expt 2 females.

For each experiment, eggs were collected by siphoning most of the water from the buckets through a Tygon ${ }^{\otimes}$, hose fitted with a Nytex filter ( $70 \mu \mathrm{m}$ mesh size). Females released their eggs at night and eggs were, therefore, collected by 07:00 h so that they were all $<6 \mathrm{~h}$ old. The remaining water containing the concentrated eggs was then gathered by gently pouring the contents of the bucket into a beaker. Samples were then transferred from the beaker to petri dishes. Eggs were sorted with a glass Pasteur micropipette under a binocular microscope and introduced into quartz incubation tubes (50 eggs tube ${ }^{-1}$ ) that had been filled with filtered seawater. We could not filter out all of the fecal pellets pre- 

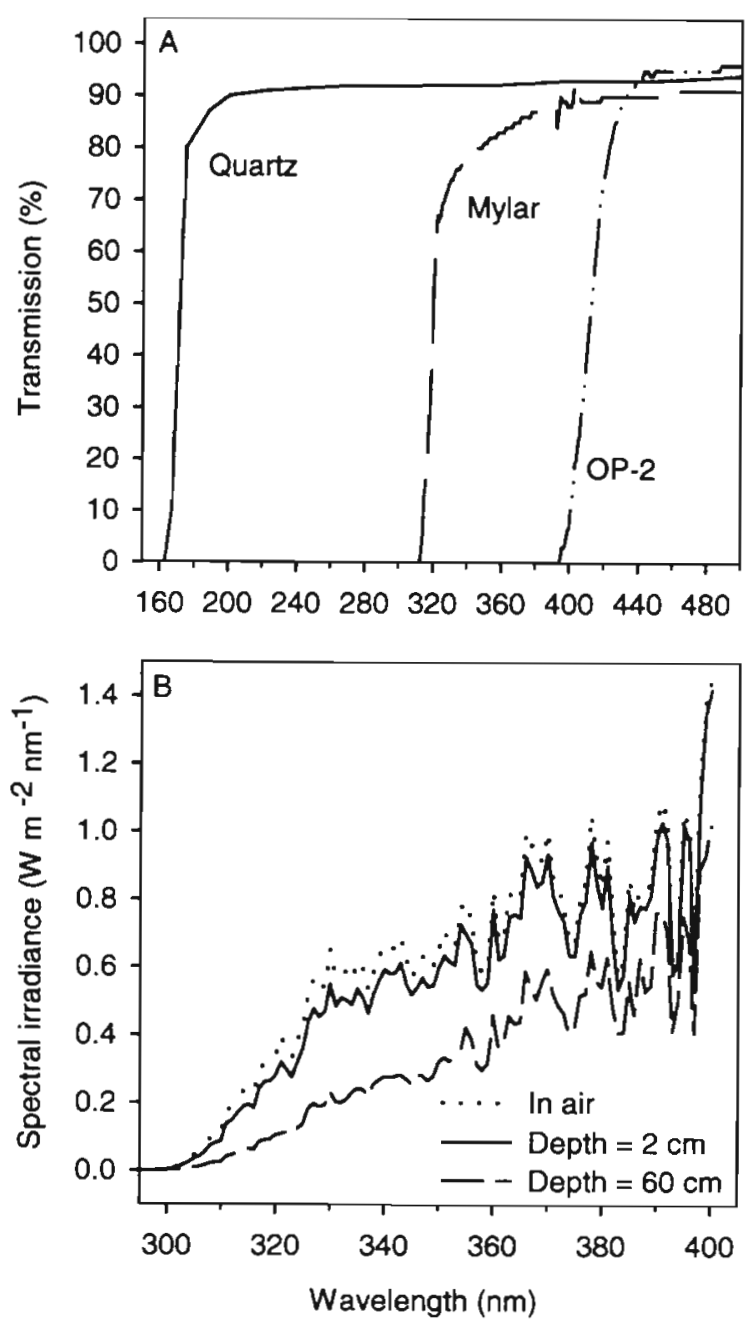

Fig. 1. (A) Spectral transmission curves for the Quartz, Mylar and OP-2 materials used to generate the spectral exposure treatments. (B) Spectral irradiance in the UV (280 to $400 \mathrm{~nm}$ ) recorded in the air and at 2 and $60 \mathrm{~cm}$ depth in the experimental reservoir at the Maurice-Lamontagne Institute, Québec, Canada (48 $38^{\circ} 25.9^{\prime \prime} \mathrm{N}, 68^{\circ} 09^{\prime} 21.0^{\prime \prime}$ W). Measurements were taken at noon on a cloudless day (14 July 1997) sent in the water from the buckets since the pellets were approximately the same size as the eggs. Thus, there was some organic matter in the tubes together with the eggs. The incubation tubes were $10 \mathrm{~cm}$ long and had an inner diameter of $22 \mathrm{~mm}$. They were sealed with plastic stoppers placed over both ends. Thus, there was no water circulation through the tubes.

Incubation procedures. Tubes were incubated in the reservoir at depths of 2 and $60 \mathrm{~cm}$. The tubes were suspended horizontally (along their long axis) from racks and the eggs, which were negatively buoyant, rested on the bottom in 1 layer only. 3 spectral exposure treatments were used (at both depths) by covering some of the tubes with UV-blocking filters and leaving others uncovered. Tubes protected with $0.05 \mathrm{~mm}$ thick Mylar$\mathrm{D}^{\mathrm{TM}}$ (Dupont) were exposed to UV-A and photosynthetically active radiation $(P A R=400$ to $700 \mathrm{~nm})=\mathrm{My}$ lar treatment. Those covered with OP- $2^{\mathrm{TM}}$ (an acrylic sheet material manufactured by Cyro Industries) received only PAR radiation = OP-2 treatment. Unprotected tubes were exposed to the full solar spectrum = Quartz. The spectral exposure treatments produced by these materials were as expected (Fig. 1A).

In the first experiment, a subset of tubes was incubated simultaneously in a temperature-controlled room (at $7.5^{\circ} \mathrm{C}$ ). They were wrapped with aluminium foil and considered as controls, although the experimental conditions were not identical: temperature was somewhat higher in the outdoor reservoir $\left(9.8 \pm 0.6^{\circ} \mathrm{C}\right.$ at midday) and it fluctuated throughout the day. In Expts 2 and 3, dark controls were placed in the reservoir. However, in Expt 3, the control group was lost, so it could not be included in the analysis. Despite the inconsistencies in these dark control groups, the experiments did all have a consistent relative controlsince the OP-2 treatment did not receive any UV radiation, it can also be considered as a control (within the context of an analysis of UV effects).

Three experiments were conducted during the summer of 1997. Details of these incubations are provided in Table 1. The difference in duration of the experi-

Table 1. Duration of daytime (light) and nighttime (dark) exposures (approximations based upon sunrise and sunset times), total incident integrated UV-B irradiance during each experiment (from the Brewer instrument), and water temperature in the experimental reservoir during the outdoor incubations of Calanus finmarchicus eggs

\begin{tabular}{|c|c|c|c|c|c|}
\hline Expt & $\begin{array}{l}\text { Incubation dates } \\
\text { and times (1997) }\end{array}$ & $\begin{array}{c}\text { Duration of daytime } \\
\text { exposure }\end{array}$ & $\begin{array}{l}\text { Duration of dark } \\
\text { exposure }\end{array}$ & $\begin{array}{l}\text { Total UV-B exposure } \\
\qquad\left(\mathrm{kJ} \mathrm{m}^{-2}\right)\end{array}$ & $\begin{array}{c}\text { Mean temperature } \\
\left({ }^{\circ} \mathrm{C}\right)\end{array}$ \\
\hline 1 & $\begin{array}{l}14 \mathrm{Jul}, 14: 45 \mathrm{~h}- \\
16 \mathrm{Jul}, 12: 00 \mathrm{~h}\end{array}$ & 28 h $32 \mathrm{~min}$ & $17 \mathrm{~h} 92 \mathrm{~min}$ & 175 & $9.8 \pm 0.62$ \\
\hline 2 & $\begin{array}{l}6 \mathrm{Aug}, 12: 00 \mathrm{~h}- \\
8 \mathrm{Aug}, 09: 00 \mathrm{~h}\end{array}$ & 25 h $42 \min$ & 18 h $48 \mathrm{~min}$ & 145 & $9.7 \pm 0.0$ \\
\hline 3 & $\begin{array}{l}20 \text { Aug, } 12: 30 \mathrm{~h}- \\
23 \text { Aug, 09:00 h }\end{array}$ & $38 \mathrm{~h} 10 \mathrm{~min}$ & 30 h $21 \mathrm{~min}$ & 90 & $7.8 \pm 0.4$ \\
\hline
\end{tabular}




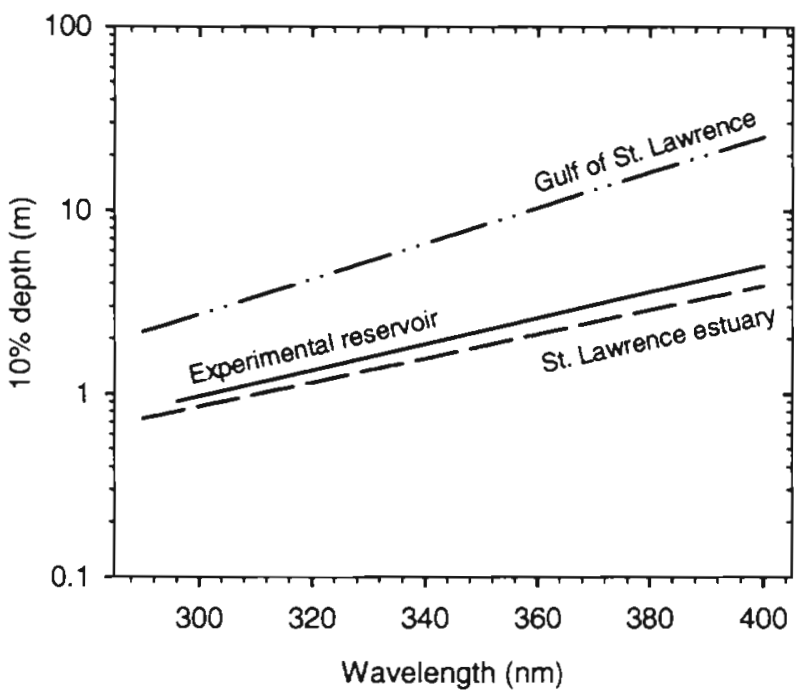

Fig. 2. Wavelength-specific $10 \%$ depth penetrations in the experimental reservoir as compared to those measured at stations in the estuary and Gulf of St. Lawrence at which Calanus finmarchicus eggs are found. The estuary station was located at $69^{\circ} 22^{\prime} 89^{\prime \prime} \mathrm{N}, 48^{\circ} 10^{\prime} 39^{\prime \prime} \mathrm{W}$ - this was nearby the site at which the experiments were conducted. The Gulf station was located at $59^{\circ} 50^{\prime} 53^{\prime \prime} \mathrm{N}, 49^{\circ} 07^{\prime} 25^{\prime \prime} \mathrm{W}$-these were the clearest waters abserved in the region (see Kuhn et al. 1999). The lines plotted are smoothed regressions fit to the raw data

ments follows from seasonal changes in water temperature, which decreased from Expt $1\left(9.8 \pm 0.6^{\circ} \mathrm{C}\right.$ at midday) to Expt $3\left(7.8 \pm 0.4^{\circ} \mathrm{C}\right)$ and affected the time to hatching.

The effect of UV radiation on hatching was determined at the end of the incubation period by counting the number of nauplii (both alive and dead) present in each tube. Owing to the small size of the eggs $(150 \mathrm{~km})$, in some cases it was impossible to recover all 50 eggs (as unhatched eggs + nauplii). Although we could not determine the reason for this, they were probably lost during the manipulations both at the beginning and at the end of the experiment. Therefore, in Expts 2 and 3, only tubes in which $>90 \%$ of the eggs were recovered were included in the analysis. In Expt 1 the number of recovered eggs and nauplii was so low that we had to decrease the threshold for inclusion and consider tubes with $>74 \%$ of the initial number remaining. For this reason, the number of replicates between treatments and experiments was variable, ranging from 3 to 8 . There was no systematic pattern of egg loss amongst treatments. Further, egg loss was not likely a result of their having died and quickly disintegrated, since in test trials it took longer than 2 to $3 \mathrm{~d}$ for dead eggs (killed by heat shock) to disintegrate.

Statistical analysis. The percentage of eggs that had hatched at the end of each experiment was calculated for each incubation tube. Percent hatching was arcsine transformed and 2-way ANOVAs (on spectral exposure and depth) were performed on each of the 3 independent experiments to test for any differences among treatments. Since the number of replicates differed amongst treatments, the cell size in these ANOVAs was unbalanced, and this reduced the statistical power of the analyses. If a significant difference was present, Bonferroni multiple comparison tests (Sokal \& Rohlf 1995) were conducted in order to isolate the source(s).

\section{RESULTS}

\section{Radiometry}

The penetration of UV radiation into the reservoir's water column was slightly greater than that recorded for estuarine waters of the St. Lawrence system (Fig. 2). This was to be expected, since the water input to the reservoir was filtered. However, penetration of UV radiation in the clearer Gulf of St. Lawrence waters was significantly higher than that of the reservoir (Fig. 2). There was essentially no measurable radiation (underwater) below $300 \mathrm{~nm}$.

There was no clear and consistent relationship between daily incident UV-B irradiance and percent hatching in the UV-B-exposed treatment (Table 1 , Fig. 3).

Response to solar exposure. In all 3 experiments, spectral exposure had a significant effect on the percentage of Calanus finmarchicus eggs that hatched (Table 2). In general, C. finmarchicus eggs exposed to natural UV radiation (Quartz and Mylar treatments)

Table 2. Summary of the 2-way ANOVAs performed on percent hatching of Calanus finmarchicus eggs exposed to natural UV radiation. Percent hatching was tested against spectral exposure treatment (Quartz, Mylar, OP-2 and controls) and depth $(2$ and $60 \mathrm{~cm})$ in each of the 3 experiments independently

\begin{tabular}{|lllllrr|}
\hline Expt & Effect & df & SS & MS & $F$ & \multicolumn{1}{c}{ p } \\
\hline 1 & Spectral exposure & 3 & 0.264 & 0.0879 & 43.254 & $<0.001$ \\
& Depth & 1 & 0.004 & 0.004 & 1.811 & 0.190 \\
& Interaction & 3 & 0.0013 & 0.0004 & 0.206 & 0.892 \\
2 & Spectral exposure & 3 & 2.94 & 0.98 & 10.825 & $<0.001$ \\
& Depth & 1 & 0.605 & 0.605 & 6.684 & 0.014 \\
& Interaction & 3 & 0.198 & 0.066 & 0.728 & 0.543 \\
3 & Spectral exposure & 2 & 0.279 & 0.14 & 8.328 & 0.002 \\
& Depth & 1 & 0.16 & 0.16 & 9.518 & 0.005 \\
& Interaction & 2 & 0.284 & 0.142 & 8.474 & 0.002 \\
\hline
\end{tabular}



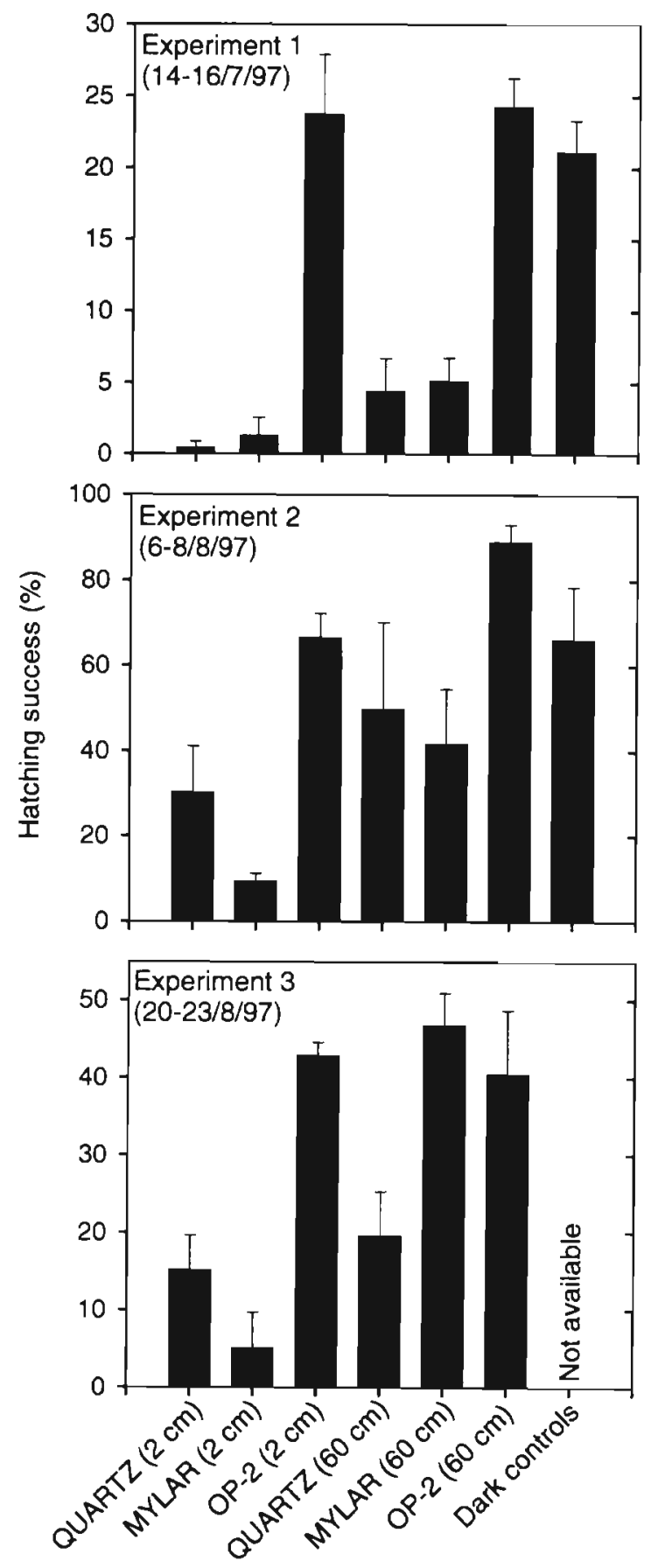

Spectral exposure

Fig. 3. Percent hatching (mean + standard error) in Calanus finmarchicus eggs exposed to natural sunlight in an outdoor reservoir at the Maurice-Lamontagne Institute, Québec, Canada $\left(48^{\circ} 38^{\prime} 25.9^{\prime \prime} \mathrm{N}, 68^{\circ} 09^{\prime} 21.0^{\prime \prime} \mathrm{W}\right)$ during the summer of 1997. Naked quartz vials were exposed to the full solar spectrum (Quartz); Mylar-wrapped vials were exposed to UV-A and visible radiation (Mylar); OP-2-covered vials were exposed only to visible radiation (OP-2) and the dark controls were wrapped with aluminium foil. There were no dark controls in Expt 3 Note that the $y$-axis scale differs from panel to panel
Table 3. Summary of the pairwise multiple comparison tests (Bonferroni $t$-test) performed on percent hatching of Calanus finmarchicus eggs exposed to natural UV radiation. The 3 experiments and the 2 different exposure depths, were analysed seperately. When reading down the columns, any pairwise comparison for which different letters are listed were different at the alpha $=0.05$ level of probability. For example, in Expt 1, hatching in the Dark and OP-2 treatments was not different but hatching in the OP-2 and Mylar treatments was

\begin{tabular}{|cccc|}
\hline Expt & Treatment & Surface & $60 \mathrm{~cm}$ depth \\
\hline 1 & Dark control & A & A \\
& OP-2 & A & A \\
& Mylar & B & B \\
2 & Quartz & B & B \\
& Dark control & A & AB \\
& OP-2 & A & A \\
& Mylar & B & B \\
3 & Quartz & AB & B \\
& OP-2 & A & A \\
& Mylar & B & A \\
& Quartz & B & B \\
\hline
\end{tabular}

exhibited lower hatching than those that were protected from UV (OP-2 and dark controls) (Table 3, Fig. 3). This was consistent for all experiments, and at both incubation depths, with the exception of Expt 3 at $60 \mathrm{~cm}$ (for which Mylar was not significantly different from OP-2) (Table 3). Further, hatching in UV-Bexposed eggs (Quartz treatment) was not significantly lower than that in eggs exposed to UV-A only (Mylar treatment), except in Expt 3 at $60 \mathrm{~cm}$ (Table 3, Fig. 3). Hatching in UV-A-exposed eggs was significantly lower than that in UV-protected eggs (OP-2), except in Expt 3 at $60 \mathrm{~cm}$ (Table 3).

There was no statistically discernible effect of incubation depth on percent hatching in Expt 1. In Expt 2, percent hatching in both the Mylar and the OP-2 treatments were lower at the surface than at $60 \mathrm{~cm}$ (Bonferroni $t$-test, $\mathrm{p}<0.05$ ). In Expt 3 , only percent hatching in the Mylar treatment was significantly lower at the surface than at depth (Bonferroni $t$-test, $\mathrm{p}<0.05$ ).

\section{DISCUSSION}

The effects of solar irradiation on Calanus finmarchicus were investigated by Harvey (1930), who found that exposure to direct sunlight decreased their heartbeat. He also observed that blue light was more effective in reducing their heartbeat than either red or green. Several more recent studies have shown that UV-B radiation is harmful to planktonic crustaceans; for example, UV-B radiation decreased survival in copepods (Ringelberg et al. 1984, Dey et al. 1988), in euphasiids, in the larval stages of shrimp and crab 
(Damkaer \& Dey 1982) and in cladocerans (Siebeck \& Böhm 1994, Zagarese et al. 1994). Furthermore, UV-B radiation reduced fecundity in copepods (Karanas et al. 1981, Williamson et al. 1994) and induced a shift in the sex-ratio of the intertidal copepod Tigriopus californicus (Chalker-Scott 1995).

Kouwenberg et al. (1999) demonstrated that Calanus finmarchicus eggs are highly susceptible to artificial UV-B radiation, particularly in the 280 to $312 \mathrm{~nm}$ waveband. However, the exposure conditions in those experiments were different from those in the present work: integrated irradiance in the UV-B waveband was higher than for natural sunlight and eggs were only exposed to UV radiation for a short time $\left(1 \mathrm{~h} \mathrm{~d}^{-1}\right)$. Nonetheless, the biological weighting function reported by Kouwenberg et al. (1999) reflects strong UVB effects, as is typical for such weighting functions (Cullen \& Neale 1997).

In this study, there was a significant difference between the UV-exposed (Quartz and Mylar) and the UV-protected (OP-2 and dark controls) treatments: Calanus finmarchicus eggs were negatively affected by ambient levels of solar UV radiation. Further, percent hatching in eggs exposed to both UV-B and UV-A was not significantly lower than that in eggs exposed to UV-A only: under natural sunlight, UV-A radiation appeared to be more detrimental to $C$. finmarchicus embryos than UV-B. It is possible, however, that the low percent hatching in these 2 treatments, the high variability among replicates, and the low statistical power, resulting from several missing replicates, masked any difference in their response to UV-B exposure. Further, the Mylar material used in these experiments transmits some energy at the UV-B-UV-A transition (13\% transmission at $315 \mathrm{~nm} ; 49 \%$ at $320 \mathrm{~nm}$, Fig. 1), so the eggs in the Mylar treatments were exposed to some UV-B radiation. Given the high weightings for exposures at these wavelengths (Kouwenberg et al. 1999), this amount of energy may have been enough to kill the eggs. It is possible, therefore, that wavelengths at the UV-B-UV-A transition are at least partly responsible for the low percent hatching in the Quartz and Mylar treatments of our experiments. The boundaries of the UV-B and UV-A wavebands have been established based on ozone absorption profiles (Lubin \& Frederick 1991). Given the variety of biological and biochemical effects induced by UV radiation, all of them wavelength-dependent, it is not always appropriate, nor biologically relevant, to be bounded by these arbitrary limits.

Another possibility is that eggs were killed by longer wavelengths of UV-A radiation. The effect of UV-A radiation on biological systems remains unclear (Sutherland et al. 1992). While its role in DNA photorepair has been well documented (Sutherland 1981, Hearst
1995, Mitani et al. 1996), fewer studies have demonstrated its deleterious effects on aquatic organisms. However, UV-A radiation inhibits photosynthesis in Antarctic diatoms and dinoflagellates, and in freshwater algae (Cullen et al. 1992, Bothwell et al. 1994). Furthermore, UV-A radiation induced a transitory decrease in the metabolic rate of the cichlid fish Cichlasoma nigrofasciatum (Winckler \& Fidhiany 1996a), a lower hatching success in embryos of the Japanese medaka Oryzias latipes (Bass \& Sistrun 1997) as well as increased mortality in eggs of the yellow perch Perca flavescens (Williamson et al. 1997) and in the freshwater copepod Boeckella gracilipes (Zagarese et al. 1997). Unlike UV-B, UV-A-induced damage does not result from direct absorption of photons by the DNA molecule (Beer et al. 1993). Although wavelengths as long as $365 \mathrm{~nm}$ induce detectable levels of cyclobutane pyrimidine dimers (Ahmed \& Setlow 1993), one of the main UV-B photoproducts in the DNA molecule (Hearst 1995), the action spectrum for DNA damage indicates that the relative biological response to wavelengths beyond $310 \mathrm{~nm}$ is negligible (Setlow 1974).

UV-A radiation is absorbed by organic molecules other than DNA, such as proteins, lipids and RNA. The dissipation of the absorbed energy via photochemical reactions generates a variety of by-products (hydroxyl radicals, superoxide, hydrogen peroxide and singletstate oxygen) which can accumulate and cause significant oxidative damage to cross-link membrane lipids and other cellular components (Lesser \& Shick 1989 and references therein, Beer et al. 1993). Pigments such as melanin or the carotenoids are known to act as free-radical scavengers and energy transducers (Hessen 1994), but Calanus finmarchicus eggs are unpigmented. Moreover, interaction between UV and dissolved organic matter (DOM) present in the water can also produce reactive oxygen transients which subsequently have cytotoxic effects (Zepp et al. 1987). This mechanism of damage occurs over a relatively longer time frame than direct damage to DNA since it results from cumulative physiological stress. This might explain why Kouwenberg et al. (1999) did not find a UVA effect: in those experiments, C. finmarchicus eggs received only 1 h of exposure to UV-A per day.

Percent hatching in the dark controls was lower than is typical for Calanus finmarchicus eggs (approximately $80 \%$, P. Joly pers. comm.). Salinity variations in the reservoir water during the exposure period would not have affected the eggs, since the tubes were closed. Temperature was not monitored throughout the day, but $C$. finmarchicus eggs are tolerant of a broad range of temperatures $\left\{-2\right.$ to $20^{\circ} \mathrm{C}$, Marshali \& Orr 1972)-they were not exposed to extremes in these experiments. One possible explanation for the low percent hatching is that the manipulations in- 
volved in the collection and transfer of the eggs at the start of the experiments caused subtle damage to the egg membrane, even though eggs still appeared viable. In Expt 1, in which percent hatching was generally very low, a food quality problem could also be involved. The eggs used in this experiment came from females that had been fed exclusively on Skeletonema costatum for approximately $6 \mathrm{wk}$. Although this diatom is not detrimental to the hatching success of $C$. finmarchicus (Ban et al. 1997), the monospecific diet could have had a negative impact on the biochemical composition of the eggs, and on their viability. The fact that the dark controls in this experiment were kept in the laboratory, yet still exhibited low percent hatching, suggests that the generally low percent hatching in all treatments was related to a problem in the quality of the eggs and not to the experimental conditions (such as low oxygen or disease) in the reservoir incubations.

If the eggs were stressed prior to the outdoor incubations, then any other stress factor (such as UV radiation) could have acted synergistically and exacerbated its effects. There are examples of synergism between UV-B radiation and pathogens (Kiesecker \& Blaustein 1995), $\mathrm{pH}$ (Long et al. 1995), nutritional status of the exposed organism (Zellmer 1996) and pollutants (Joshi \& Misra 1986). UV-A radiation can also interact synergistically with temperature (Winckler \& Fidhiany 1996b) and pollutants (Kagan et al. 1987).

Depth affected percent hatching only in the Mylar and OP-2 treatments of Expt 2, and the Mylar treatment in Expt 3. Percent hatching was always lower at the surface. This difference probably results from the attenuation of UV light with depth (Fig. 1). More consistent depth-related differences were likely undetected as a result of the high variability within each treatment and/or the low percent hatching

In these experiments, Calanus finmarchicus eggs received ecologically realistic UV dose rates and daily UV doses. The wavelength-specific $10 \%$ depth penetrations in the reservoir were similar to those observed in this organism's estuarine habitat (Fig. 2 and see Kuhn et al. 1999). However, $10 \%$ depths in the Gulf of St. Lawrence, where C. finmarchicus is also very abundant, are higher (Fig. 2). Thus, the UV impacts on $C$. finmarchicus eggs recorded here would underestimate those that might occur in the waters of the Gulf of St. Lawrence. Thus, eggs residing at depths of 0 to $4 \mathrm{~m}$ in the natural environments of this region are susceptible to UV radiation. However, our experimental design did not attempt to simulate the vertical mixing dynamics of the surface layer. In an experiment in which vertical cycling was simulated, Zagarese et al. (1998a,b) found that the freshwater cladoceran Ceriodaphnia dubia (a species capable of photorepair) was more susceptible to UV radiation when it was incubated at a fixed depth than when it was artificially mixed in the water column. On the other hand, Boeckella gracilipes, a species without the ability to photorepair, exhibited the opposite response. The difference was apparently due to the photorepair ability of C. dubia. This implies that both vertical mixing and the capacity for photorepair play a major role in the UV tolerance of planktonic organisms. If C. finmarchicus eggs are capable of photorepair, UV exposure would result in less severe net photodamage in their natural environment than the results presented here suggest. We have not as yet tested photoreactivation potential in C. finmarchicus eggs. However, other calanoid copepods do have this capacity (Naganuma et al. 1997, Zagarese et al. 1997).

The results of these experiments suggest that, at current levels of exposure, UV radiation (particularly UV-A) has a negative effect on Calanus finmarchicus eggs residing in the upper layers of the ocean. Additional information on the vertical distribution (at very fine scales in the upper $5 \mathrm{~m}$ of ther water column) and mixing dynamics of $C$. finmarchicus eggs, and other planktonic organisms, is needed in order to assess the impact of UV radiation on these planktonic early life stages. The role of UV-A as a deleterious environmental parameter also needs to be more thoroughly investigated.

Acknowledgements. We are grateful for the help of F. Béland, M. Bélanger, Pierre Joly, J. H. M. Kouwenberg and M. Starr during the experiments. We also thank P. Kuhn for her valuable suggestions and technical assistance with the radiometric measurements. The insightful comments and suggestions of Michael Arts, and 3 anonymous reviewers, significantly improved the quality of the presentation. This project was supported by grants in aid of research from the Department of Fisheries and Oceans Canada, the St. Lawrence Action Plan 2000, and the Natural Sciences and Engineering Research Council of Canada (NSERC) to H.I.B. and J.A.R. C.A.R. was supported by a stipend from H.I.B.'s NSERC operating grant and by a Foreign Student Tuition Fee Waiver from the Government of Québec.

\section{LITERATURE CITED}

Ahmed FE, Setlow RB (1993) Ultraviolet radiation-induced DNA damage and its photorepair in the skin of the platyfish Xiphophorus. Cancer Res 53:2249-2255

Ban S, Burns C, Castel J, Chaudron Y, Christou E, Escribano R, Fonda Umani S, Gasparini S, Guerrero Ruiz F, Hoffmeyer $M$, lanora $M$, Kang $H K$, Laabir $M$, Lacoste $A$, Miralto A, Ning X, Poulet S, Rodriguez V, Runge J, Shi J, Starr M, Uye S, Wang Y (1997) The paradox of diatomcopepod interactions. Mar Ecol Prog Ser 157:287-293

Bass EL, Sistrun SN (1997) Effect of UVA radiation on development and hatching success in Oryzias latipes, the Japanese medaka. Bull Environ Contam Toxicol 59: $537-542$

Beer JZ, Olvey KM, Miller SA, Thomas DP, Godar DE (1993) 
Non-nuclear damage and cell lysis are induced by UVA, but not UVB or UVC, radiation in three strains of L5178Y cells. Photochem Photobiol 58:676-681

Booth CR, Morrow JH (1997) The penetration of UV into natural waters. Photochem Photobiol 65:254-257

Bothwell ML, Sherbot D, Roberge AC, Daley RJ (1993) Influence of natural ultraviolet radiation on lotic periphytic diatom community growth, biomass accrual, and species compostion: short-term versus long-term effects. J Phycol 29:24-35

Bothwell, ML, Sherbot DMJ, Pollock CM (1994) Ecosystem response to solar ultraviolet-B radiation: influence of trophic-level interactions. Science 265:97-100

Cabrera S, Lopez M, Tartarotti B (1997) Phytoplankton and zooplankton response to ultraviolet radiation in a highaltitude Andean lake: short- versus long-term effects. J Plankton Res 19:1565-1582

Chalker-Scott L (1995) Survival and sex ratios of the intertidal copepod, Tigriopus californicus, following ultraviolet-B $(290-320 \mathrm{~nm})$ radiation exposure. Mar Biol 123:799-804

Cullen JJ, Neale PJ (1997) Biological weighting functions for describing the effects of ultraviolet radiation on aquatic systems. In: Häder DP (ed) The effects of ozone depletion on aquatic ecosystems. RG Landes, Austin, p 97-118

Cullen JJ, Neale PJ, Lesser MP (1992) Biological weighting function for the inhibition of phytoplankton photosynthesis by ultraviolet radiation. Science 258:646-650

Damkaer DM. Dey DB (1982) Short-term responses of some planktonic crustacea exposed to enhanced UV-B radiation. In: Calkins $J$ (ed) The role of solar ultraviolet radiation in marine ecosystems. Plenum Press, New York, p $417-427$

de Lafontaine X, Demers S, Runge J (1991) Pelagic food web interactions and productivity in the Gulf of St. Lawrence: a perspective. In: Therriault JC (ed) The Gulf of St. Lawrence: small ocean or big estuary? Can Spec Publ Fish Aquat Sci 113:99-123

Dey DB, Damkaer DM, Heron GA (1988) UV-B/dose responses of seasonally abundant copepods of Puget Sound Oecologia 76:321-329

Goes JI, Handa N, Taguchi S, Hama T (1994) Effect of UVB radiation on the fatty acid composition of the marine phytoplankter Tetraselmis sp.: relationship to cellular pigments. Mar Ecol Prog Ser 114:259-274

Häder DP, Worrest RC, Kumar HD, Smith RC (1995) Effects of increased solar ultraviolet radiation on aquatic ecosystems. Ambio 24:174-180

Hairston NG Jr (1979) The adaptive significance of color polymorphism in two species of Diaptomus (Copepoda). Limnol Oceanogr 24:15-37

Harvey JM (1930) The action of light on Calanus finmarchicus (Gunner) as determined by its effect on the heart rate. Contrib Can Biol Fish 5:85-92

Hearst JE (1995) The structure of photolyase: using photon energy for DNA repair. Science 268:1858-1859

Hessen DO (1994) Daphnia responses to UV-light. Arch Hydrobiol Beih Ergebn Limnol 43:185-195

Holm-Hansen O, Lubin D. Helbling EW (1993) Ultraviolet radiation and its effects on organisms in aquatic environments. In: Young AR, Björn LO, Moan J, Nultsch W \{eds\} Environmental UV photobiology. Plenum Press, New York, p 379-425

Joshi PK, Misra RB (1986) Evaluation of chemically-induced phototoxicity to aquatic organisms using Paramecium as a model. Biochem Biophys Res Comm 139:79-84

Kagan J, Sinott D, Kagan ED (1987) The toxicity of pyrene in the fish Pimephales promelas: synergism by piper- onyl butoxide and by ultraviolet light. Chemosphere 16: 2291-2298

Kane J (1984) The feeding habits of co-occurring cod and haddock larvae from Georges Bank. Mar Ecol Prog Ser 16: 9-20

Karanas JJ, Worrest RC, Van Dyke H (1981) Impact of UV-B radiation on the fecundity of the copepod Acartia clausii. Mar Biol 65:125-133

Kiesecker JM, Blaustein AR (1995) Synergism between UVB radiation and a pathogen magnifies embryo mortality in nature. Proc Natl Acad Sci USA (Ecology) 92:11049-11052

Koutitonsky VG, Bugden GL (1991) The physical oceanography of the Gulf of St. Lawrence: a review with emphasis on the synoptic variability of the motion. Can Spec Publ Fish Aquat Sci 113:57-90

Kouwenberg JHM, Browman HI, Runge JA, Cullen JJ, Davis RF, St-Pierre JF (1999) Biological weighting of ultraviolet $(280-400 \mathrm{~nm})$ induced mortality in marine zooplankton and fish. Il.Calanus finmarchicus eggs. Mar Biol 134: $285-293$

Kuhn P, Browman HI, St-Pierre JF, McArthur B (1999) Penetration of ultraviolet radiation in the waters of the estuary and Gulf of St. Lawrence. Limnol Oceanogr 44:710-716

Lesser MP, Shick JM (1989) Effects of irradiance and ultraviolet radiation on photoadaptation in the zooxanthellae of Aiptasia pallida: primary production, photoinhibition and enzymic defenses against oxygen toxicity. Mar Biol 102 $243-255$

Long LE, Saylor LS, Soule ME (1995) pH/UVB synergism in amphibians. Conserv Biol 9:1301-1303

Lubin D, Frederick JE (1991) The ultraviolet radiation environment of the Antarctic peninsula: the roles of ozone and cloud cover. J Appl Meteorol 30:478-493

Marshall SM, Orr AP (1972) The biology of a marine copepod Oliver and Boyd, London

Mitani H, Uchida N, Shima A (1996) Induction of cyclobutane pyrimidine dimer photolyase in cultured fish cells by UVA and blue light. Photochem Photobiol 64:943-948

Morgan SG, Christy JH (1996) Survival of marine larvae under the countervailing selective pressures of photodamage and predation. Limnol Oceanogr 4 1:498-504

Naganuma T, Inoue $T$, Uye S (1997) Photoreactivation of UVinduced damage to embryos of a planktonic copepod. J Plänkton Res 19:783-787

Ringelberg J, Keyser AL, Flik BJG (1984) The mortality effect of ultraviolet radiation in a translucent and in a red morph of Acanthodiaptomus denticornis (Crustacea, Copepoda) and its possible ecological relevance. Hydrobiologia 112 $217-222$

Runge JA, de Lafontaine $Y$ (1996) Characterization of the pelagic ecosystem in surface waters of the northern Gulf of St. Lawrence in early summer: the larval redfishCalanus-microplankton interaction. Fish Oceanogr 5: 21-37

Runge JA, Plourde S (1996) Fecundity characteristics of Calanus finmarchicus in coastal waters of eastern Canada. Ophelia 44:171-187

Setlow RB (1974) The wavelengths in sunlight effective in producing skin cancer: a theoretical analysis. Proc Natl Acad Sci USA 71:3363-3366

Siebeck O, Böhm U (1994) Challenges for an appraisal of UVB effects upon planktonic crustaceans under natural radiation conditions with a non-migrating (Daphnia pulex obtusa) and a migrating cladoceran (Daphnia galeata). Arch Hydrobiol Beih Ergebn Limnol 43:197-206

Siebeck $O$, Vail TL, Williamson CE, Vetter R, Hessen D, Zagarese H, Little E, Balseiro E, Modenutti B, Seva J, Shu- 
mate A (1994) Impact of UV-B radiation on zooplankton and fish in pelagic freshwater ecosystems. Adv Limnol 43:101-114

Sokal RR, Rohlf FJ (1995) Biometry. WH Freeman and Company, New York

Sutherland BM (1981) Photoreactivation. Bioscience 31: $439-444$

Sutherland BM, Hacham H, Gange, RW, Sutherland JC (1992) Pyrimidine formation by UVA radiation: implications for photoreactivation. In: Urbach F (ed) Biological responses to ultraviolet A radiation. Valdenmar, Overland Park, KS, p $47-58$

Williamson CE, Zagarese HE, Schulze PC, Hargreaves BR, Seva J (1994) The impact of short-term exposure to UV-B radiation on zooplankton communities in north temperate lakes. J Plankton Res 16:205-218

Williamson CE, Metzgar SL, Lovera PA, Moeller RE (1997) Solar ultraviolet radiation and the spawning habitat of yellow perch, Perca flavescens. Ecol Appl 7:1017-1023

Winckler K, Fidhiany L (1996a) Significant influence of UVA on the general metabolism in the growing Cichlid fish, Cichlasoma nigrofasciatum. J Photochem Photobiol (Ser B) 33:131-135

Winckler K, Fidhiany L (1996b) Combined effects of constant sublethal UVA irradiation and elevated temperature on

Editorial responsibility: Otto Kinne (Editor),

Oldendorf/Luhe, Germany the survival and general metabolism of the convict-cichlid fish, Cichlasoma nigrofasciatum. Photochem Photobiol 63 $487-491$

Zagarese HE, Williamson CE, Mislivets M, Orr P (1994) The vulnerability of Daphnia to UVB radiation in the Northeastern United States. Arch Hydrobiol Beih Ergebn Limnol 43:207-216

Zagarese HE, Feldman M, Williamson CE (1997) UV-Binduced damage and photoreactivation in three species of Boeckella (Copepoda, Calanoida). J Plankton Res 19: $357-367$

Zagarese HE, Cravero W, Gonzalez P, Pedrozo F (1998a) Copepod mortality induced by fluctuating levels of natural ultraviolet radiation simulating vertical water mixing. Limnol Oceanogr 43:169-174

Zagarese HE, Tartarotti B, Cravero W, Gonzalez P (1998b) UV damage in shallow lakes: the implications of water mixing. J Plankton Res 20:1423-1433

Zellmer ID (1996) The impact of food quantity on UVB tolerance and recovery from UVB damage in Daphnia pulex. Hydrobiologia 319:87-92

Zepp RG, Braun AM, Hoigné J, Leenheer JA (1987) Photoproduction of hydrated electrons from natural organic solutes in aquatic environments. Environ Sci Technol 21. $485-490$

Submitted: February 3, 1999; Accepted: October 13, 1999

Proofs received from author(s): February 18, 2000 